\title{
Pembinaan Usaha Pariwisata Mandiri Di Desa Labulia Kecamatan Jonggat Kabupaten Lombok Tengah
}

\author{
Lalu Hendra Maniza ${ }^{1}$, Sulhan Hadi $^{2}$, Ramayanto ${ }^{3}$, Jasmina ${ }^{4}$ \\ ${ }^{1234}$ Universitas Muhammadiyah Mataram \\ manizahendra@gmail.com
}

\begin{abstract}
Abstrak; Pengabdian Kepada Masyarakat ini berjudul "Pembinaan Usaha Pariwisata Mandiri Di Desa Labulia Kecamatan Jonggat Kabupaten Lombok Tengah”. Pengabdian ini dilakukan dengan beberapa tujuan, pertama, untuk meningkatkan kesadaran tentang potensi pariwisata bagi masyarakat di Desa Labulia Kabupaten Lombok Tengah; kedua, untuk memberikan pengetahuan pariwisata bagi masyarakat di Desa Labulia Kabupaten Lombok Tengah dan ketiga, untuk memberikan pengetahuan manajemen usaha di bidang pariwisata bagi masyarakat di Desa Labulia Kabupaten Lombok Tengah. Metode yang diterapkan adalah tatap muka dan diskusi. Hasil yang diperoleh dari Pengabdian Kepad aMasyarakat ini adalah bertambahnya pengetahuan bagi para peserta yang dalam hal ini adalah masyarakat di Desa Labulia tentang kesadaran pentingnya pariwisatadalam manajemen usaha dibidang pariwisata.
\end{abstract}

Kata kunci:Pembinaan Usaha ,Pariwisata Mandiri, Desa Labulia.

Abstract; This dedication to the community was entitled "The Development Of Independent Tourism Business In Labulia Village, Jonggat District, Central Lombok District". This service is carried out with several objectives, first, to raise awareness about the potential of tourism for the community in Labulia Village, Central Lombok Regency; second, to provide tourism knowledge for the community in Labulia Village, Central Lombok Regency and third, to provide business management knowledge in the field of tourism for the community in Labulia Village, Central Lombok Regency. The method applied is face to face and discussion. The results obtained from this Community Service Devotion were increased knowledge for the participants in this case the community in Labulia Village about the awareness of the importance of tourism in business management in tourism.

\section{PENDAHULUAN}

Nusa Tenggara Barat (NTB) merupakan daerah yang mempunyai potensi yang memungkinkan pertumbuhan, pengembangan wilayahserta ekonomi berbasis pada pariwisata. Bagi provinsi ini pariwisata merupakan sektor utama pertumbuhan ekonomi. Berdasarkan hasil penelitian Oktaryani dan Permadi (2013) diketahui terjadi peningkatan kunjungan wisatawan yang signifikan berkunjung ke NTB selama tahun 2008 - 2011 yang diiringi dengan peningkatan tingkat hunian kamar hotel,hal tersebut mendorong naikknya Produk Domestik Regional Bruto (PDRB) dari sektor perdagangan, hotel dan restoran. Peningkatan di sektor pariwisata itu turut mendorong peningkatan pertumbuhan ekonomi daerah dan menggerakkan sektor lain yang terkait seperti jasa tranportasi dan komunikasi.

Meningkatnya wisatawan yang datang ke di daerah NTB ini tidak hanya didukung oleh wisata alam, tetapi juga wisata budaya dimana keragaman kebudayaan, nilai, tradisi, adat, suku, yang ada di NTB memiliki nilai wisata yang tinggi. Salah satu kabupaten yang memiliki potensi pariwisata alam dan budaya adalah Lombok Tengah.Kabupaten Lombok Tengah terbentuk menjadi Daerah Otonom berdasarkan Undangundang Nomor 69 Tahun 1958 tentang Pembentukan Daerah-Daerah Tingkat II dalam Wilayah Daerah-Daerah Tingkat I Bali, Nusa Tenggara Barat dan Nusa Tenggara Timur. Undang-undang tersebut disahkan pada Tanggal 14 Agustus 1958.

Secara keseluruhan, angka kemiskinan di Nusa Tenggara Barat tergolong masih tinggi, dan Kabupaten Lombok Tengah tingkat angka dkemiskinan didaerahh masih lebih tinggi jika dibandingkan dengan daerah lain. Seperti Lombok Barat, Lombok Timur dan Kabupaten Lombok Utara (KLU) yang masih memiliki angka kemiskinan penduduk lebih rendah .Banyaknya program pembangunan yang digalakkan 
pemerintah, terutama pada kawasan yang masih tergolong dalam ekonomi lemah, bisa merubah kemiskinan yang ada. Salah satu cara mengatasi masalah kemiskinan tersebut, perlu dikedepankan konsep pemberdayaan masyarakat. Diantaranya dengan pemberian pelatihan kewirausahaan di bidang pariwisata agar mereka dapat meningkatkan kesejahteraan hidupnya.Selain itu, penciptaan wirausahawan baru di bidang pariwisata juga dapat menciptakan lapangan kerja baru yang mampu menyerap tenaga kerja lokal.

Desa Labulia merupakan salah satu desayang berada diwilayah Kecamatan Jonggat yang terletak di Kabupaten Lombok Tengah dengan batas Sebelah Utara : Desa Ubung, Sebelah Selatan : Desa Desa Ranggata, Sebelah Timur : Desa Suka Rara dan Sebelah Barat : Selat Kuripan. Desa Labulia sendiri terbagi menjadi 9 (sepuluh) Dusun yaitu: Dusun Labulia, Dusun Tandek, Dusun Olor Agung, Dusun Dasan Sebeleq, Dusun Enjak, Dusun Batu Tinggang, Dusun Sulin, Dusun Tomber dan Dusun Embung Duduk.Untuk meningkatan kesejahteraan masyarakat, maka penduduk di desa ini perlu dibekali ilmu dan ketrampilan sehingga mereka lebih termotivasi untuk berwirausaha di bidang pariwisata.Ini mengingat potensi wisata di desa ini sangat bagus tapi belum dimaksimalkan.

Mengingat potensi yang besar tersebut dan melihat pembangunan sektor pariwisata yang sedemikian maju dikabupaten Lombok Tengah , akan sangat disayangkan ketika penduduk asli yang berdiam didaerah tersebut tidak ikut menikmati bagian dari pembangunan pariwisata yang dilaksanakan,jangan sampai penduduk lokal menjadi penonton didaerah sendiri.

Demi mendukung program pemberdayaan masyarakat di bidang pariwisata dan pertumbuhan usaha kecil, kami memandang perlu adanya kegiatan pengabdian pada masyarakat yang ditujukan untuk memberi pelatihan tentang pariwisata dan manajemen usaha produktif bagi para pengusaha kecil dan juga masyarakat di desa Labuliayang tertarik untuk berwirausaha di bidang pariwisata.Dalam pelatihan tersebut akan diberikan pengetahuan terbaru seperti tentang sejarah potensi peluang usaha dibidang pariwisata ,seperti peluang untuk menjadi pemandu wisata,membuat makanana khas atau kerajinan untuk oleholeh,usaha penginapan maupun transportasi.

Abdi Masyarakat
Mitra dalam pengabdian kepada masyarakat adalah Kelompok Sadar Wisata (Pokdarwis) dan Masyararakat Desa Labulia Kecamatan Jonggat Kabupaten Lombok Tengah, beberapa masalah yang dihadapi dari hasil analisis situasi dapat di identifikasi sebagai berikut :

1. Desa Labulia merupakan salah satu desa gerbang masuk untuk wisatawan yang ingin mengunjungi pantai Kuta dan Sirkuit moto gp melalui jalan by pass selatan

2. Kurangnya pengetahuan masyarakat potensi bisnis pariwisata yang muncul akibat pembangunan yang begitu masiv di sektor pariwisata

3. Kurangnya kesadaranmasyarakat di Desa Labulia bahwa di desa mereka tersimpan potensi yang besar untuk pengembangan bisnis pariwisata.

Berdasarkan permasalahan yang dihadapi oleh mitra, beberapa alternatif solusi yang dapat ditawarkan adalah sebagai berikut, yaitu:

1. Memberikan penyuluhan kepada masyarakat untuk menyadarkan mereka bahwa lokasi desa mereka sangat strategis dan harus dimamfaatkan untuk dapat meningkatkan kesejahteraan penduduk setempat.

2. Memberikan penyuluhan kepada masyarakat sehingga mereka mengetahui potensi bisnis apa saja yang muncul dengan adanya pengembangan disektor pariwisata.

Target yang ingin dicapai melalui kegiatan penyuluhan ini adalah agar masyarakat merangsang semangat kewirausaan terutama dibidang pariwisata khususnya penduduk desa Labulia, Kecamatan Jonggat Lombok Tengah sehingga mereka mampu meningkatkan kesejahteraan dibidang ekonomi.

Luaran

a. Terbentuknya kelompok karang taruna yang perduli dengan pembangunan desa terutama dalam upaya meningkatkan kesejahteraan penduduk setempat melaui kesadaran untuk mandiri dengan berwirausaha.

b. Publikasi di : Journal of Character Education Society (UMMAT) 
Alur Pelaksanaan Kegiatan

1. Persiapan administrasi

2. Rapat Koordinasi

3. Survey Lokasi kegiatan

4. Persiapan kegiatan

5. Pelaksanaan Kegiatan

6. Monitoring dan evaluasi Kegiatan

7. Laporan Kegiatan

8. Publikasi

\section{Metode Pelaksanaan Kegiatan}

Penyampaian materi pembinaan usaha pariwisata mandiri disampaikan kepada para peserta dilakukan dalam dua bentuk, yaitu:

1. Pertama dalam bentuk penyampaian materi mengenai potensi bisnis pariwisata

2. Kedua, melakukan penyuluhan mengenai bisnis apa saja yang muncul dari sektor pariwisata dan cara mendirikan serta mengelola bisnis tersebut.

\section{Pemateri}

Pemateri dalam kegiatan ini adalah pelaku bisnis pariwisata Nusa Tenggara Barat dan dari Dinas Pariwisata Kabupaten Lombok Tengah serta dosen Ilmu Admisnitrasi Bisnsi Universitas Muhammadiyah Mataram

\section{Rencana Evaluasi}

Evaluasi dari keberhasilan pelatihan ini akan dilihat dari kehadiran peserta dan keaktifan pada saat pelatihan dilaksanakan. Bila peserta aktif bertanya dan berdiskusi, maka kegiatan ini dikatakan berhasil. Yang hadir pada saat kegiatan berlangsung hampir 95\% yaitu undangan 70 orang, yang tidak hadir sebanyak 5. Peserta aktif bertanya, sehingga terbentuk diskusi dan interaksi yang sangat menarik.

\section{Keberlanjutan}

Kegiatan pengabdian ini diharapkan dapat berkelanjutan, utamanya dalam mendorong kesadaran masyarakatuntuk berwirausaha terutama disektor pariwisata yang menjadi sektor andalan kabupaten lombok tengah dan NTB pada umumnya.

\section{Hasil Pelaksanaan Kegiatan}

Sektor pariwisata telah membuktikan mampu memberikan kontribusi yang signifikan bagi penerimaan devisa negara, sehingga pembangunan dalam sektor ini sangat menjadi perhatian khusus pemerintah, bahkan pemerintah merencanakan menjadikan sektor pariwisata ini menjadi penyumbang Abdi Masyarakat devisa negara terbesar ditahun-tahun mendatang.

Rencana ini tercermin dalam program pemerintah yang akan mambuat "new balines" dimana pemerintah telah menetapkan lima kawasan strategis pariwisata nasional (KSPN) atau Bali Baru dengan status super prioritas, yakni di Danau Toba (SUMUT), Borobudur (Magelang), Mandalika (Lombok), Bunaken ( Sulawesi) dan Bangka belitung.

di Provinsi Nusa Tenggara Barat, pariwisata sudah menjadi sektor prioritas untuk dikembangkan secara totalitas, mengingat banyaknya spot-spot yang bisa di jadikan obyek wisata ditempat ini, apalagi dengan dibangunnya sirkuit balap kelas dunia Moto GP, hal ini akan membuat sektor pariwisata didaerah ini akan semakin menggeliat dan akan mampu memberikan multiplier effect terhadap sektor barang maupun jasa yang pada ahirnya tentu akan mampu membuat perekonomian semakin maju.

Melihat potensi yang besar ini tentunya ini tidak boleh diabaikan begitu saja termasuk oleh para penduduk lokal, jangan sampai mereka nanti menjadi penonton didaerah sendiri oleh karena itu dalam rangka melihat potensi bisnis yang muncul dari sektor pariwisata dan untuk menyiapkan SDM yang unggul dan berdaya saing dibidang pariwisata, kami dosen Program Studi Administrasi Bisnis Fakultas Ilmu Sosial Dan Politik Universitas Muhamadiyah Mataram melaksanakan Seminar dan pelatihan mengambil tema "Pembinaan Usaha Pariwisata Mandiri Di Desa Labulia Kecamatan Jonggat Kabupaten Lombok Tengah"

Lokasi pelaksanaankegiatan dilakukan di Aula Kantor Desa Labulia yang dapatm enampung sejumlah pesertayang sudahdipilih yaitu Kepala Dusun dari 16 Dusun dan tokoh masyarakat serta Karang Taruna khususnya masyarakat yang memiliki minat untuk berwirausaha mandiri disektor pariwisata .

Pemateri dalam kegiatan sosialisasi ini pelaku bisnis pariwisata Nusa Tenggara Barat utusan dari Dinas Pariwisata Kabupaten Lombok Tengah, beliau memberikanmateri pentingnya membangun kemandirian 
ekonomi dalam upaya untuk meningkatkan kesejateraan keluarga dan masyarakat lebih lanjut pemateri mengatakan bahwa daerah Nusa Tenggara Barat dan Kabupten Lombok Tengah saat ini sedang menjadi pusat perhatian dunia terutama dibidang pariwisata, terbukti dengan berbagai penghargaan kaliber internasional yang didapatkan belum lagi even kelas dunia Moto GP akan digelar di kabupaten Lombok Tengah, tentunya hal ini akan membawa dampak atau multiplier effect yang besar bagi daerah, jangan sampai penduduk lokal hanya bisa menjadi penonton. Penduduk lokal harus ambil bagian dari perkembangan pariwsata ini. Banyak bisnis yang bisa dilakukan dalam sektor pariwisata, diantaranya; bisnis transportasi, bisnis oleholeh, bisnis penginapan maupun pemandu wisata.

Adapun dampak dari pelaksanaan kegiatan Pengabdian Kepada Masyarakat ini adalah bertambahnya pengetahuan bagi para peserta tentang besarnya potensi bisnis pariwisata yang ada didaerah ini, sehingga masyarakat mampu untuk menumbuhkembangkan sekaligus merangsang semangat kewirausahaan demi tercapainya kesejahteraan dan kemakmuran bersama.

\section{KESIMPULAN}

Melalui kegiatan ini para peserta di Desa Puyung dapat mengetahui bisnis apa saja yang mereka bisa geluti disektor pariwisata serta bagiamana cara memulainya dan bagimana cara pengelolaan bisnis tersebut ketika sudah berjalan bail dari aspek, sumber daya manusia, keuangan, pasar maupun produksinya. Diharapkan setelah kegiatan ini mereka mampu untuk melakukan tindakan untuk aktif dalam proses pembentukan semangat kewirausahaan serta mampu menularkan semangat tersebut kepada masyarakat luas, sehingga akan muncul pengusaha-pengusaha mandiri yang baru yang mampu ikut serta dalam membangun negara menuju kemakmuran dan kesejahteraan.

\section{SARAN}

Program Pengabdian Kepada Masyarakat ini sangat bermanfaat dalam upaya memeberikan pengetahuan tentang pentingnya berwirausahan demi mecapai kehidupan yang diinginkan, terutama dalam Abdi Masyarakat sektor pariwisata yang saat ini sedang gencar dibangun oleh pemerintah. Data menunjukkan bahwa tingakt kunjungan wisatawan didaerah ini terus meningkat dari tahun ketahun yang mengartikan bahwa sektor ini sangat menjanjikan dan peluang tersebut harus mampu ditangkap dengan baik sehingga masyarakat lokal bisa menjadi pelaku bisnis disektor ini dan bukan hanya menjadi penonton.

Sebaiknya program Pengabdian Kepada Masyarakat ini dapat terus berlanjut sehingga muncul wirausaha-wirausaha baru yang mampu mengisi pembangunan terutama pembangunan disektor pariwisata sehingga masyarakat bisa mensukseskan cita-cita para founding father kita yakni mewujudkan kesehateraan bagi seluruh rakyat indonesia.

\section{Daftar Pustaka}

Bennet, Jeff. 1993. Rafting ! The Complete Guide To Whitewater Techniques \& Equipment.

Bintarto, R dan Surastopo Hadisumarto. 1987. Metode Analisis Geografi. LP3ES. Jakarta.

Darsoprajitno, Soewarno. Jawa Barat Berbakat Menjadi Tujuan Wisata Yang Mempesona. DPD Perhimpunan Obyek Wisata Indonesia "Putri”. Bandung. 